\title{
Young Consumer Green Purchase Behavior
}

\author{
Sohaib Zafar \\ University of Education Lahore, Multan campus, Pakistan \\ E-mail: ik81638@gmail.com \\ Atif Aziz \\ College of Management Sciences \\ Karachi institute of economics and technology, Pakistan \\ E-mail: atif.aziz@pafkiet.edu.pk \\ Muhammad Hainf \\ University of education Lahore, Pakistan \\ E-mail:malikhanif1556@gmail.com
}

\begin{abstract}
Environmental pollution is increasing day by day which is causing serious threats to our planet. Global warming, increase in temperature, melting of glaciers are some of issues which the world is facing now. Due to ease of information sharing and technology business across the globe has become quite easier and businesses are operating in whole world. Multinationals are working in whole world. Business is one of the sources of pollution. The production process, supply chain process and many other processes from manufacturing to end product cause pollution. So, to prevent Earth from pollution concept of green marketing emerged which means to produce products which are eco-friendly and then promote these products through ecofriendly ways. The main aim of a company is to satisfy consumers. So, company keeps focus on the factors which forces the consumer to buy the product. Consumer can be motivated by various factors while purchasing product. In this paper those factors are discussed and their effect is measured on green purchase behavior. According to environmental performance index Pakistan is among top 12 countries which are affected by pollution. Meanwhile according to DAWN newspaper 2019 Pakistan has largest population of youngsters in history. So, this paper investigates the factors that influence green purchase behavior of young students.
\end{abstract}

Keywords: Green Purchase Behavior, Altruism, Environmental Knowledge, Interpersonal Influence, Environmental Attitude.

\section{Introduction}

Due to hazards to environment, green marketing has gained importance. According to Mintu \& Lozada (I993) green marketing is implementation of marketing tools that not only satisfy organization and consumer needs but it preserve, protect, and conserve physical environment. According to American Marketing Association, Yazdanifard \& Mery (20II) green marketing is approach to marketing whose focal point is environmental safety which includes activities like packaging, modification, green ads, and production process.

Environmentally concern consumers pay leading role in reducing problems related to environment (Laroche, Bergeron \& Barbavo-Ferleo, 200I; Mustafa, 2006; Zelezny et al., 2000; Milfont, 20I2,) like in other continents, in Asia green marketing has also become popular.(Gurau \& Ranchod, 2005 ; Khan \& Kirmani,2015 ; Uddin \& Khan,2016).Marketers are showing great interest in ecological climate. Organizations lack of interest in environmental issues encouraged consumers to shift their focus towards green movement (Mandelson \& Polonsky, 1995). Companies are trying to gain competitive advantage over other firms by applying different strategically approaches and by relocating consumers thinking using green products (Elham Rahbar, 20II).

Trust, Belief, taste of young customer depends upon external and internal factors. Internal factors are usually psychological factors like needs, motivations, personality and characteristics, ability to learn (Olejniczak-Merto, 2009, p5253).External factors are economic, cultural, family, groups and opinion leaders. Since, young consumers have sufficient environmental knowledge, so they act as potential force for the protection of environment.(Caruana \& Rosella , 2003). Young consumers can be influencing tool for their peers (Moses, 2000; Lee, 2009). But research of (McCrndle, 2005) disclosed that environmental awareness and peer impact did not change into actual behavior, still there is gap, a value action gap.

\section{I.I Background of Study}

Consumer purchasing pattern has been altered due to rapid growth in population. (Gruber \& Schlegelmilch, 20I4). Advancement in technology and consumption of non-sustainable products has played their part in creating problems for environment. Lancet commission report on pollution and health (2017) blamed pollution for the death of 9 million people. 
Environmental pollution has existed for centuries but got attention in $1^{\text {th }}$ century after industrial revolution (internet). According to United nations every year world uses 500 billion plastic bags, 8 million tons of plastic ends up in ocean.

(Axelrod \& Lehman I993: pg. I53) In order to determine the ecological behavior psychologists, focus on individual behavior instead of focusing the behavior of whole society (i.e. which actions will make contribution towards preservation of nature). So envitonmental attitude can answer these questions. (New house, 1990). Over last three decades vast study have been conducted to find the factors of consumer behavior. (main) Balder-jahn, 1988; Bamberg, 2003; Kaiser \& Fuhrer, 2003; Bamberg \& Moser, 2007; Chen\& Chai, 2010; Cholette et al., 2013; Punyatoya, 2014).

To gain full understanding of complexity of sustainable marketing, youngsters are perfect for research view point (Lee, 2008). Generally young consumers consider new ideas and are willing to accept innovations. (Ottman et al, 2006; Sullivan \& Heitmeyar, 2008; Hume, 2010).Youngsters are important part of market process these days.(Olejnicuk-Merta,200I).Young consumer become more important when we consider the fact that this child will become potential consumer, and he is developing his purchase behavior at his early age (Kicinka, 2009).In west researchers have studied relationship between green buying behavior and various psychographic variables. (Busse \& Menzel, 2014; Guéguen \& Stefan, 2016). Factors like interpersonal influence, environmental concern, altruism, skepticism, perceived environmental responsibility, environmental knowledge, and environmentalattitude have significance in exploitation of green buying behavior. (Bearden et al., 1989; Laroche et al., 1996; Chan \& Lau, 200I; Kaiser \& Gutscher, 2003; Cleveland et al., 2005; Lueg \& Finney, 2007; Albayrak, 201 I; Wesley et al., 2012; Guéguen \& Stefan, 2016; Nguyen, Lobo, \& Nguyen, 2017).

According to DAWN (2019) Pakistan has largest percentage of young people in its history. According to UNDP report $64 \%$ of population is below 30 while $29 \%$ are between I5 to 29 years. As Pakistan has largest percentage of youngsters so they can play leading role in protection of environment. Since youngsters have innovative mindset and they have knowledge, they can be source of promotions of green products. So, this study explores the relationship between green purchasing behavior and factors such as knowledge, altruism, interpersonal influence, and environmental attitude in the context of young consumers of Pakistan.

\section{I.3 Problem Statement}

Due to increase in world population, consumption of consumers is increasing which leads to pollution i. Pollution is creating serious threats for our plant. Change in weather, melting of glaciers, depletion of ozone is some threats for Earth. Companies are diverting towards ecofriendly products to reduce the impact of harmful products and production procedures on environment. Consumers green buying behavior is influenced by various factors so this study tends to see the impact of various variables on green purchase behavior.

\section{I.3.I Research Gap}

Previous studies measured the impact of altruism, environmental knowledge, interpersonal influence on green purchase behavior wit mediating role environtonal attitude but this research will measure the direct influence of these variables on green purchase behavior of young consumers of Pakistan.

\section{I.4 Research Objective}

- To measure direct influence of altruism

- To measure direct influence of, environmental knowledge on green purchase behavior

- To measure direct influence of interpersonal influence on green purchasing behavior.

\section{I.5 Research Question}

- What is impact of altruism on green purchase behavior of young consumer?

- What is impact of environmental knowledge on green purchase behavior of young consumer?

- What is impact of interpersonal influence on green purchase behavior of young consumer? 


\section{I.6 Research Model}

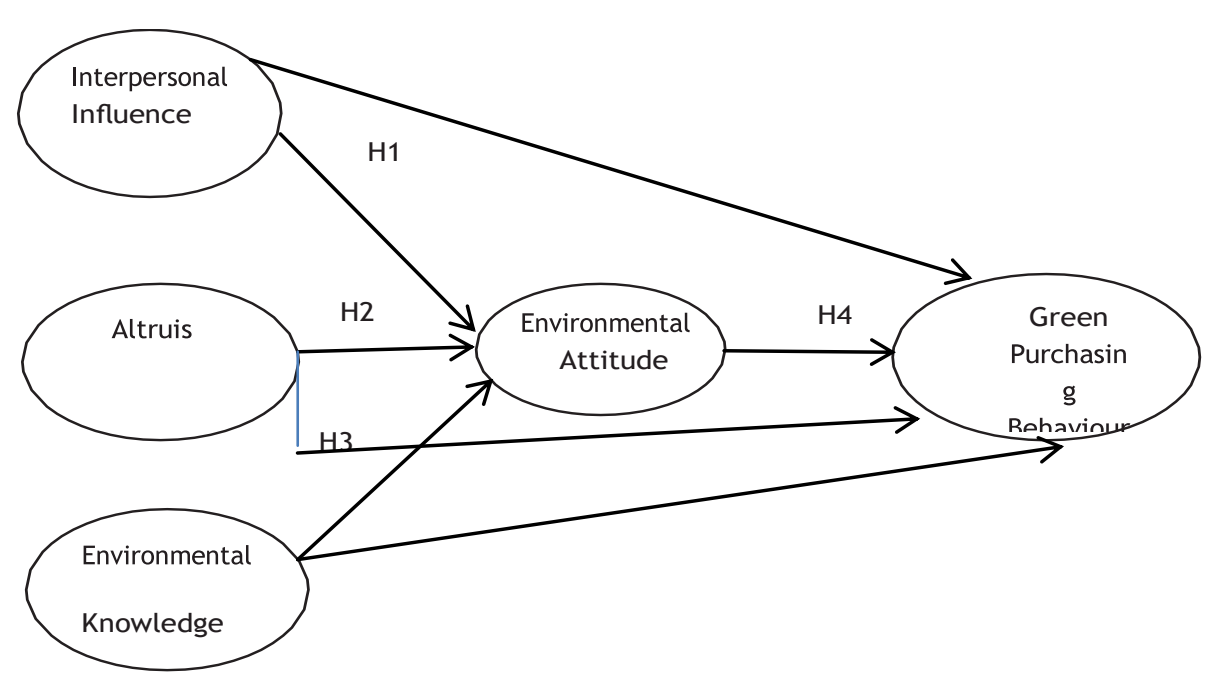

\section{Hypothesis:}

HI: There is direct influence of altruistic values on green purchase behavior

$\mathrm{H} 2$ : There is direct influence of, environmental knowledge on green purchase behavior

$\mathrm{H} 3$ : There direct influence of interpersonal influence on green purchasing behavior.

\section{Methodology}

\section{I Research Design}

This is descriptive research. Survey method was used to conduct the research. Different respondents were surveyed.

\section{I.I Instrument}

Research instrument consist of two sections. First section comprises of validated scales which were taken from previous studies. Whereas second section consist of demographic characteristics of the respondents. Research instrument consist of 5 constructs. interpersonal influence (IP), environmental knowledge (EK), altru- ism (ALT), environmental attitude (EA), and green purchasing behavior (GPB). The EK measure com- prised four statements and was adapted from (Ellen et al., (I99I); Suki 2013). Five items to measure IP were adapted from Bearden et al. (1989). There were four scale items to measure GPB, while the EA scale had five statements adapted from Lee (2009). The five items employed to measure ALT were borrowed and modified from the study by Shwartz (1977).

\subsubsection{Data collection}

English is spreading fast in Pakistan. According to Wikipedia 92 million of population has command over English language. Pakistan produces 445000 university graduates every year. This researcher-controlled sampling was employed. So final research tool was administrated on graduated and undergraduate student of different universities of Multan.

\subsubsection{Population}

The population of the research consists of English medium university of Multan. University of education Lahore, Multan campus.

\subsubsection{Sample}

Sample is the representative part of the population. So, researcher collected data from I0O students by distributing questioner for data collection pen and paper format was used.

\section{Literature Review}

\section{I Green Purchase Behavior}

The purchase of eco-friendly products and avoiding the products which are harmful avoiding the products which are harmful to environment is known as green purchase behavior (Chano, 200I). Most oftenly green purchase intention and green buying behavior are measures of green purchasing. Willingness of consumers to pay for green products is known as green purchase intention. Green purchase behavior of consumer is influenced by factors which captured by intention (Ramayah, Lee \& 
Mohammad, 2010). Green purchase behavior is regarded as socially responsible behavior. A green consumer consider himself as socially responsible consumer and he always keep in mind the public consequences that might others have to face due to his private consumption. He try to utilize his purchasing power to change the society (Morsander, 2005).

For the explanation of green purchase behavior the focal point of the previous was underlying attitudes, values and intention towards eco-friendly products ( Foxall \& Pallister,2002; Vermeir \& Verbeke, 2006; Wheale \& Hinton, 2007). The theory of reasoned action (TRA) by Ajzen \& Fishbein (I980) and the theory of planned behavior (TPB) were 2 approaches that most of the studies followed. According to TRA there are 2 factors that determine the behavior of the individual which are individual attitudes and social norms. TPB included additional factor which was individual behavior-perceived behavior control.

\subsection{Environmental Attitude}

All favorable or unfavorable responses of individual towards certain thing, place or object can be referred as attitude (khan $\&$ khan 2006). There are 3 basic components of attitude: cognitive (thinking about the object) conative (include action) affective (feeling about object) (Breckler,I984). There might be confusion with attitudes and other construct such as beliefs and values, opinions, personal norms. Although these construct to some extent relates to the components of attitudes but there is difference. ( Shrigley, Koballa \& Simpon, I988 pg 659).

Environmental attitude is explained along with similar lines. The ability to assess the condition of environmental in favorable or unfavorable responses (Milfont \& Duckitt, 2010). Green purchase behavior of individual is affected by environmental attitude (Laroche et al., 200I Lee, 200I; Akhurst et al., 2012; Zhao et al., 2014). If individual are concerned about environment, they will behave to minimize the impact of one's actions on nature and there will be positive affect on green purchase decision (Chan \& Lau, 200I; Laroche et al., 200I; Chen \& Chai, 20I0; Zsoka et al., 2013; nguyen et al., 20I7). According to previous studies, one of the most relevant factors of green purchase behavior is environmental attitude (Stern $\&$ Dietz, 1994; Lee, 20II; Akeshurst et al., 2012; Uddin \& Khan, 2016a). There is substantial impact of environmental attitude on green buying behavior of youngster (Kaise et al., 2007).

\subsection{Interpersonal Influence}

According to S.M. Fateh \& M. Naeved Khan (2018) interpersonal influence is composed of persuading others or convincing others. Interpersonal influence is widely accepted as one of determinants of individual (Bearden et al., I989; Cheah \& Phau, 20II). According to suggestion of Stanford \& Cocan.....1977 ip3) to fully understand behavior of consumer effects of interpersonal influence on formation of values, attitudes, aspiration and purchase behavior should be considered. Family and friends are the source of giving awareness about eco-friendly products to consumers friends (Cheah \& Phau, 20I I; Lim et al,, 2014). Many researchers have proposed that buying behavior of consumers is shaped by the influence of peer's consumers (Singh et al., 2006; Kaur \& Singh, 2007; Lueg \& Finney, 2007; Lee, 20II). Social groups and norms also influence attitude of consumer towards green products (Chan \& Lau, 200I; Lee, 2009; Kim \& Chung, 20II. Cheah \& Phau (20II).

\subsection{Altruism}

Definition of Matear (1993) describe altruism as kind behavior for benefit of others and without expecting any reward. Leads (1963) stated that altruism is voluntarily performed behavior that is beneficial to at least single individual and action is done without any desire or demand of any reward. Altruistic behavior is shaped by personality traits. The actions which are done with intention of helping others are called altruism. Biological and evolutionary minds tend to focus on potential benefits of particular behavior while psychologist interest is in knowing the motivation behind particular behavior. According to biological view point behavior which reduces the fitness of one individual while increasing the fitness of other individual is altruism.

\subsection{Environmental Knowledge}

Knowledge is important factor that influence the ways of customer collection, organization of information and the ways by which consumer evaluate product and services (Syahbandi, 2012). Environmental knowledge is the awareness of general public on health and welfare issues. It also includes the issues that rise from negative impact of harmful gasses, pollutants, chemicals and potential issues that affect positive attitude regarding green products (Ali et al., 20I I; Haryanto \& Budiman, 20I4). Research of (Gan et al; cited by Chen, 2013) development of environmental knowledge takes into 2 forms; consumer should able to understand effects of various products on environment through education. According to Julina (2013) one's attitude can be affected by knowledge on environment. Noor et al. (2012) is of view point that attitudes are positively influenced by environmental knowledge. According to definition of Wu \& Teg (2013) environmental knowledge is awareness of consumer regarding environmental issues. 
4. Data Analysis

Correlation

\begin{tabular}{|c|c|c|c|c|c|c|c|}
\hline & & $\begin{array}{l}\text { Interpersonal } \\
\text { Influence }\end{array}$ & $\begin{array}{l}\text { Environmental } \\
\text { Knowledge }\end{array}$ & Altruism & $\begin{array}{l}\text { Environmental } \\
\text { Attitude }\end{array}$ & $\begin{array}{l}\text { Green } \\
\text { Behavior }\end{array}$ & Purchase \\
\hline \multirow{4}{*}{$\begin{array}{l}\text { Interpersonal } \\
\text { Influence }\end{array}$} & Pearson & $\mathrm{I}$ & $.386^{\text {the }}$ & $.40 I^{\text {the }}$ & $.346^{\text {the }}$ & $.402^{\text {sh }}$ & \\
\hline & Correlation & & & & & & \\
\hline & $\begin{array}{l}\text { Sig. } \\
\text { tailed) }\end{array}$ & & .000 & .000 & .000 & .000 & \\
\hline & $\mathrm{N}$ & 99 & 98 & 99 & 99 & 99 & \\
\hline \multirow{4}{*}{$\begin{array}{l}\text { Environmental } \\
\text { Knowledge }\end{array}$} & Pearson & $.386^{\text {th }}$ & $\mathrm{I}$ & $.403^{\text {wh }}$ & $.387^{\text {sin }}$ & $.272^{\text {kn }}$ & \\
\hline & Correlation & & & & & & \\
\hline & $\begin{array}{l}\text { Sig. } \\
\text { tailed) }\end{array}$ & .000 & & .000 & .000 & .006 & \\
\hline & $\mathrm{N}$ & 98 & 99 & 99 & 99 & 99 & \\
\hline \multirow[t]{4}{*}{ Altruism } & Pearson & $.40 \mathrm{I}^{\text {th }}$ & $.403^{\text {hat }}$ & $\mathrm{I}$ & $.403^{\text {thin }}$ & $.286^{\text {th }}$ & \\
\hline & Correlation & & & & & & \\
\hline & $\begin{array}{l}\text { Sig. } \\
\text { tailed) }\end{array}$ & .000 & .000 & & .000 & .004 & \\
\hline & $\mathrm{N}$ & 99 & 99 & 100 & 100 & 100 & \\
\hline \multirow[t]{3}{*}{ Environmental Attitude } & $\begin{array}{l}\text { Pearson } \\
\text { Correlation }\end{array}$ & $.346^{\text {the }}$ & $.387^{\text {then }}$ & $.403^{\text {the }}$ & $\mathrm{I}$ & $.224^{*}$ & \\
\hline & $\begin{array}{l}\text { Sig. } \\
\text { tailed) }\end{array}$ & .000 & .000 & .000 & & .025 & \\
\hline & $\mathrm{N}$ & 99 & 99 & 100 & 100 & 100 & \\
\hline \multirow[t]{3}{*}{ Green Purchase Behavior } & $\begin{array}{l}\text { Pearson } \\
\text { Correlation }\end{array}$ & $.402^{\text {H. }}$ & $.272^{\text {wat }}$ & $.286^{\text {tht }}$ & $.224^{*}$ & $\mathrm{I}$ & \\
\hline & $\begin{array}{l}\text { Sig. } \\
\text { tailed) }\end{array}$ & .000 & .006 & .004 & .025 & & \\
\hline & $\mathrm{N}$ & 99 & 99 & 100 & 100 & 100 & \\
\hline
\end{tabular}

Regression

\begin{tabular}{cccc}
\hline \multicolumn{4}{c}{ Variables Entered/Removed $^{\mathrm{a}}$} \\
\hline Model & $\begin{array}{c}\text { Variables } \\
\text { Entered }\end{array}$ & $\begin{array}{c}\text { Variables } \\
\text { Removed }\end{array}$ & Method \\
\hline I & $\begin{array}{c}\text { Interpersonal } \\
\text { influence }^{b}\end{array}$ & $\cdot$ & Enter \\
\hline
\end{tabular}

A. Dependent Variable: Green purchase behavior b. All requested variables entered.

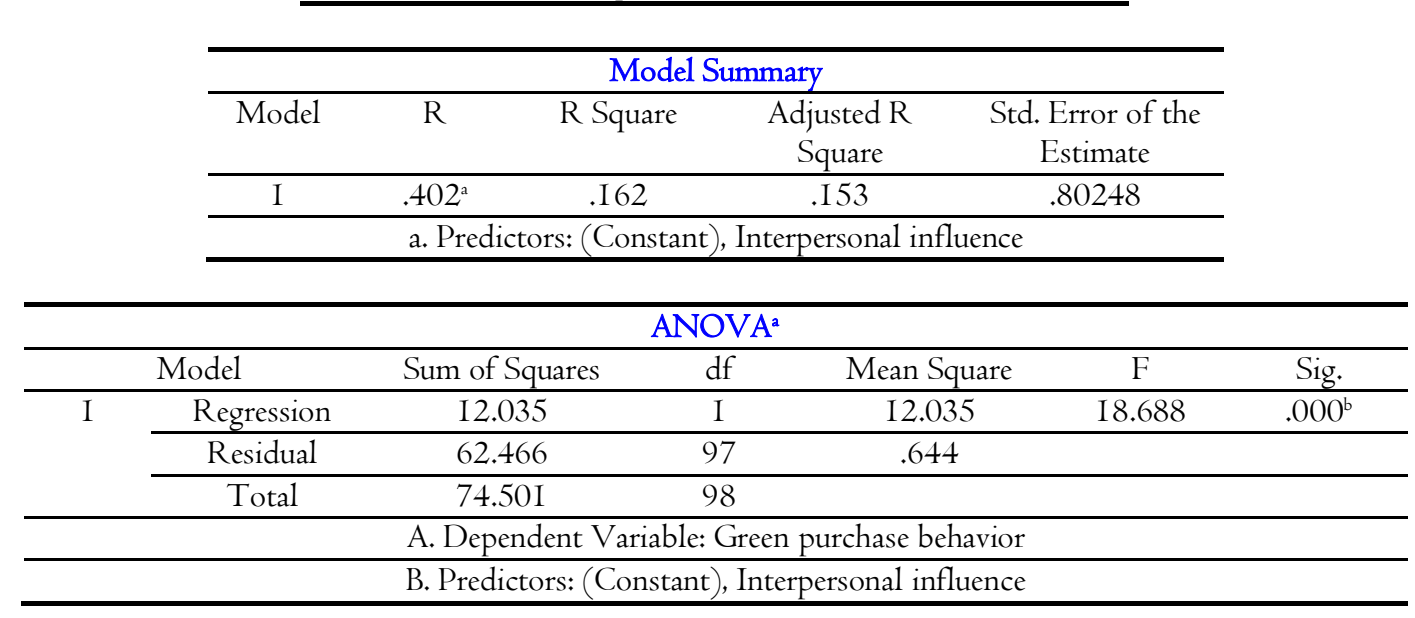




\begin{tabular}{|c|c|c|c|c|c|c|}
\hline \multicolumn{7}{|c|}{ Coefficients $^{a}$} \\
\hline \multirow{2}{*}{\multicolumn{2}{|c|}{ Model }} & \multicolumn{2}{|c|}{ Unstandardized Coefficients } & \multirow{2}{*}{$\begin{array}{c}\begin{array}{c}\text { Standardized } \\
\text { Coefficients }\end{array} \\
\text { Beta } \\
\end{array}$} & \multirow[t]{2}{*}{$\mathrm{t}$} & \multirow[t]{2}{*}{ Sig. } \\
\hline & & $\mathrm{B}$ & Std. Error & & & \\
\hline \multirow[t]{2}{*}{$\mathrm{I}$} & (Constant) & 2.272 & $.3 \mathrm{II}$ & & 7.316 & .000 \\
\hline & Interpersonal influence & .400 & .092 & .402 & 4.323 & .000 \\
\hline
\end{tabular}

Interpretation: According to above results there is positive relation between interpersonal influence and green purchase behavior. Which means that influence of other people can lead to green purchase behavior. The value of R square is .I62 so IV can change DV up to $16 \%$.

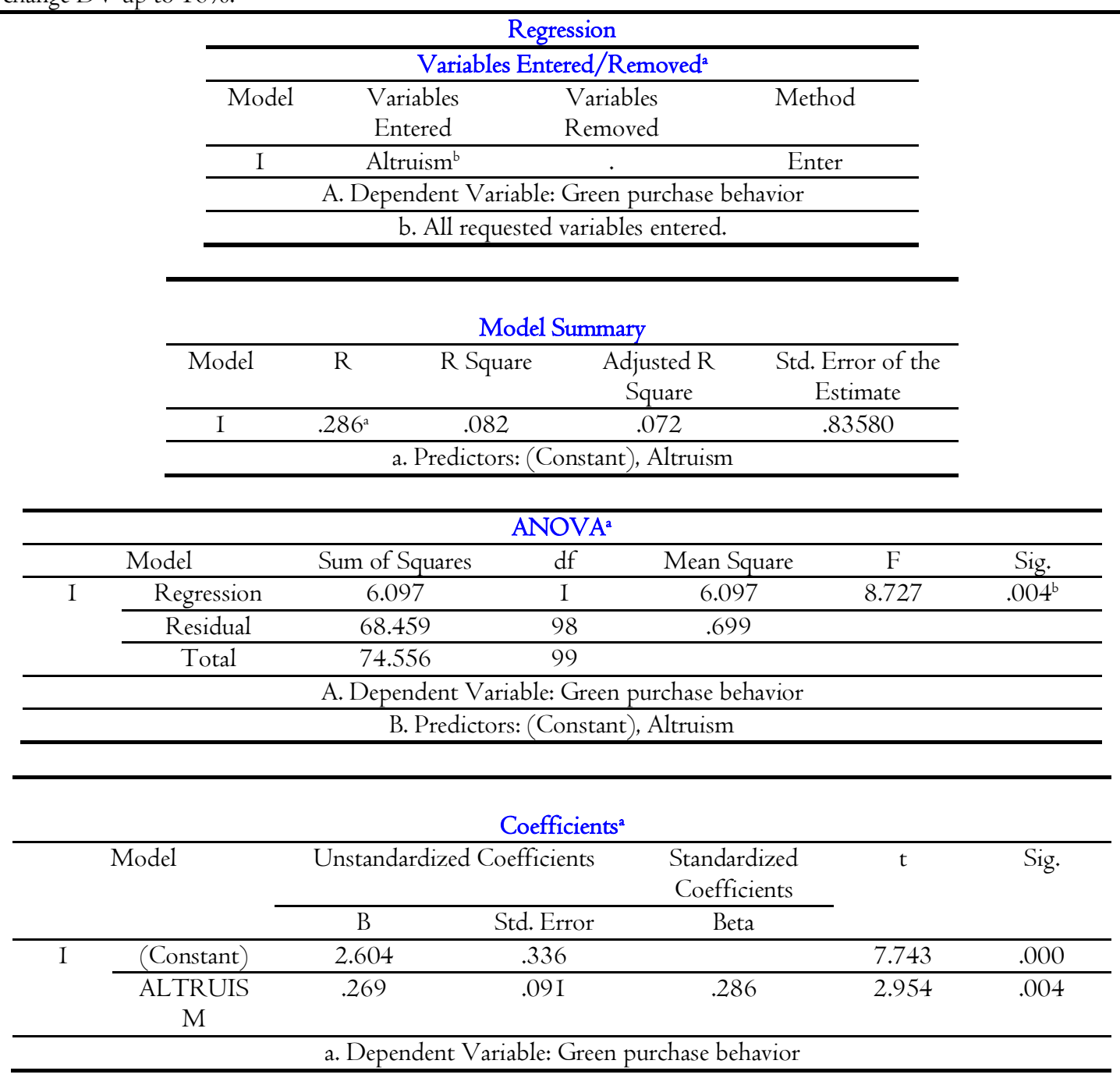

Interpretation: Above results shows that the significant value is less than 0.05 so hypothesis is accepted altruism has significant impact on green purchase behavior and altruism can influence green purchase behavior up to 8 percent.

\section{Regression}

\begin{tabular}{ccc}
\hline \multicolumn{3}{c}{ Variables Entered/Removed $^{\mathrm{a}}$} \\
\hline Model & $\begin{array}{l}\text { Variables } \\
\text { Entered }\end{array}$ & $\begin{array}{c}\text { Variables } \\
\text { Removed }\end{array}$ \\
\hline I & $\begin{array}{c}\text { Environmental } \\
\text { Knowledge }\end{array}$ & Enter \\
\hline \multicolumn{3}{c}{ a. Dependent Variable: Green purchase behavior } \\
\hline \multicolumn{3}{c}{ b. All requested variables entered. } \\
\hline
\end{tabular}




\begin{tabular}{ccccc}
\hline \multicolumn{5}{c}{ Model Summary } \\
\hline Model & $\mathrm{R}$ & $\mathrm{R}$ Square & $\begin{array}{c}\text { Adjusted R } \\
\text { Square }\end{array}$ & $\begin{array}{c}\text { Std. Error of the } \\
\text { Estimate }\end{array}$ \\
\hline $\mathrm{I}$ & $.272^{\mathrm{a}}$ & .074 & .065 & .83663 \\
\hline & A. Predictors: (Constant), Environmental knowledge \\
\hline
\end{tabular}

\begin{tabular}{ccccccc}
\hline \multicolumn{7}{c}{ ANOVA $^{\text {a }}$} \\
\hline \multirow{3}{*}{ I } & Model & Sum of Squares & df & Mean Square & F & Sig. \\
\cline { 2 - 6 } & Regression & 5.438 & I & 5.438 & 7.768 & $.006^{\text {b }}$ \\
\cline { 2 - 6 } & Residual & 67.896 & 97 & .700 & \\
\cline { 2 - 6 } & Total & 73.333 & 98 & & \\
\hline \multicolumn{5}{c}{ A. Dependent Variable: Green purchase behavior } \\
\hline
\end{tabular}

\begin{tabular}{|c|c|c|c|c|c|c|}
\hline \multicolumn{7}{|c|}{ Coefficients ${ }^{a}$} \\
\hline \multirow{2}{*}{\multicolumn{2}{|c|}{ Model }} & \multicolumn{2}{|c|}{ Unstandardized Coefficients } & \multirow{2}{*}{$\begin{array}{c}\begin{array}{c}\text { Standardized } \\
\text { Coefficients }\end{array} \\
\text { Beta }\end{array}$} & \multirow[t]{2}{*}{$\mathrm{t}$} & \multirow[t]{2}{*}{ Sig. } \\
\hline & & $\mathrm{B}$ & Std. Error & & & \\
\hline \multirow[t]{2}{*}{$\mathrm{I}$} & (Constant) & 2.665 & .330 & & $8.07 \mathrm{I}$ & .000 \\
\hline & Environmental knowledge & $.26 \mathrm{I}$ & .094 & .272 & 2.787 & .006 \\
\hline
\end{tabular}

Interpretation: According to above result significant value is 0.06 which shows that our hypothesis is rejected that there is significant relation between environmental knowledge and green purchase behavior. But environmental knowledge can influence GPB up to 7 percent.

\begin{tabular}{|c|c|c|c|}
\hline \multicolumn{4}{|c|}{ Regression } \\
\hline \multicolumn{4}{|c|}{ Variables Entered/Removed $^{a}$} \\
\hline Model & Variables & Variables & Method \\
\hline & Entered & Removed & \\
\hline $\mathrm{I}$ & $\begin{array}{c}\text { Interpersonal } \\
\text { influence }\end{array}$ & . & Enter \\
\hline \multicolumn{4}{|c|}{ A. Dependent Variable: Environmental attitude } \\
\hline \multicolumn{4}{|c|}{ b. All requested variables entered. } \\
\hline
\end{tabular}

\begin{tabular}{clccc}
\hline \multicolumn{4}{c}{ Model Summary } \\
\hline Model & $\mathrm{R}$ & R Square & $\begin{array}{c}\text { Adjusted R } \\
\text { Square }\end{array}$ & $\begin{array}{c}\text { Std. Error of the } \\
\text { Estimate }\end{array}$ \\
\hline I & $.346^{a}$ &. I I9 &. I I0 & .78229 \\
\hline \multicolumn{4}{l}{ a. Predictors: (Constant), Interpersonal influence } \\
\hline
\end{tabular}

\begin{tabular}{ccccccc}
\hline \multicolumn{7}{c}{ ANOVA $^{\text {a }}$} \\
\hline \multirow{3}{*}{$\mathrm{I}$} & Model & Sum of Squares & df & Mean Square & F & Sig. \\
\cline { 2 - 7 } & Regression & 8.053 & I & 8.053 & I3.159 & $.000^{\text {b }}$ \\
\cline { 2 - 7 } & Residual & $59.36 \mathrm{I}$ & 97 & .612 & \\
\cline { 2 - 6 } & Total & $67.4 \mathrm{I} 4$ & 98 & & \\
\hline \multicolumn{7}{c}{ A. Dependent Variable: Environmental attitude } \\
\hline
\end{tabular}

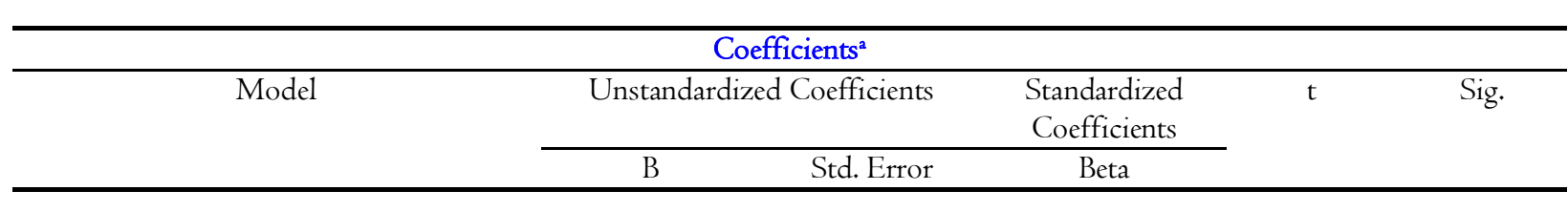




\begin{tabular}{ccccccc}
\hline \multirow{2}{*}{$\mathrm{I}$} & (Constant) & 2.545 & .303 & 8.407 & .000 \\
\cline { 2 - 7 } & Interpersonal influence & .327 & .090 & .346 & 3.627 & .000 \\
\hline
\end{tabular}

Interpretation: The significant value is .000 which means that there is perfect relation between interpersonal influence and environmental attitude. While value of $\mathrm{R}$ square is $I I \%$ which means that interpersonal influence can influence environmental attitude up t0 II percent.

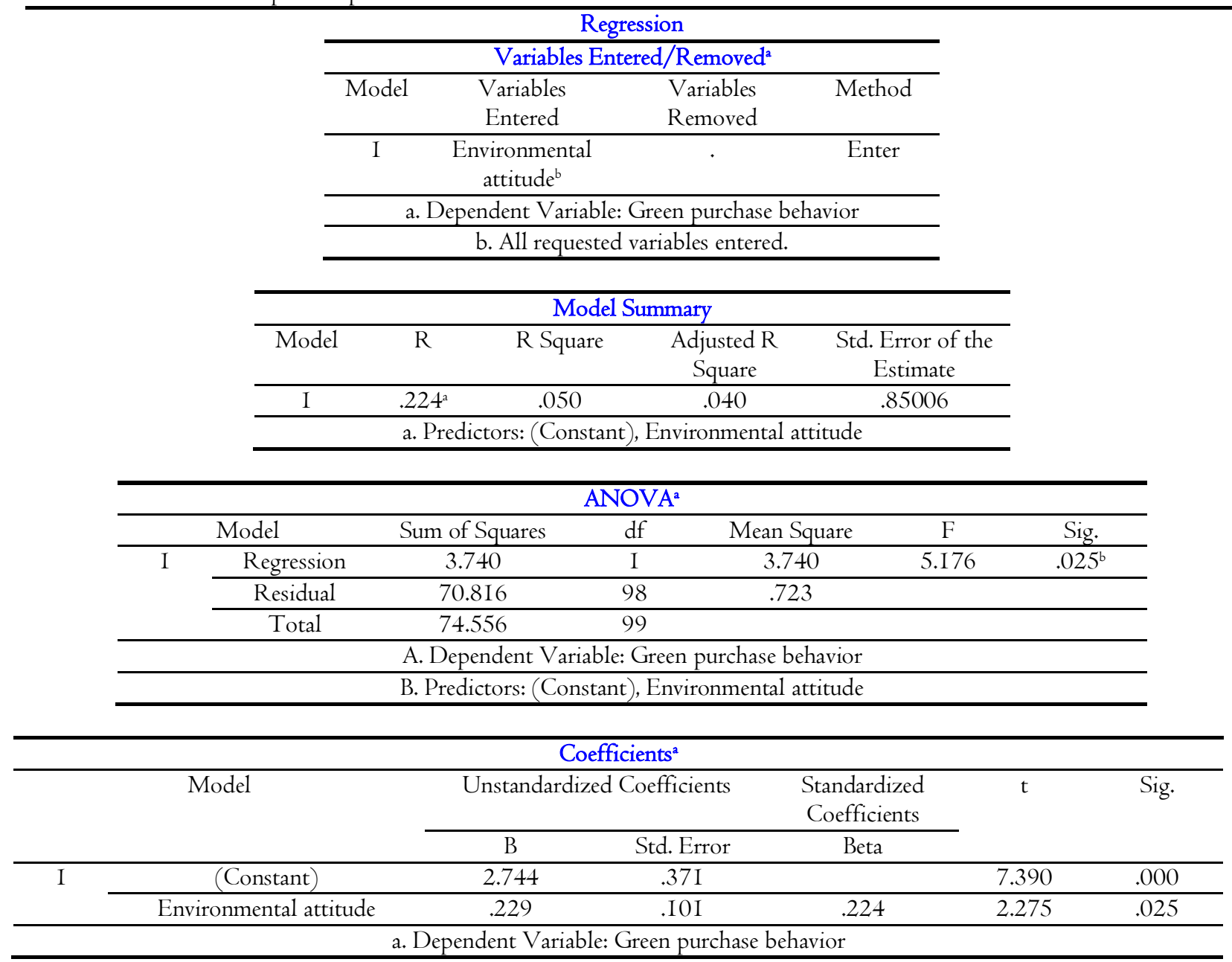

Interpretation: According to ANOVA table value of significant is 0.25 which is less than 0.05 so our hypothesis is accepted that there is significant relationship between green purchase behavior and environmental attitude. The value of $\mathrm{R}$ square is 0.50 which means environmental attitude can influence GPB up to $5 \%$

\section{Regression}

\begin{tabular}{cccc}
\hline \multicolumn{4}{c}{ Variables Entered/Removed $^{\mathrm{a}}$} \\
\hline Model & Variables & Variables & Method \\
& Entered & Removed & \\
\hline I & ALTRUISM & . & Enter \\
\hline \multicolumn{4}{c}{ a. Dependent Variable: Environmental Attitude } \\
\hline \multicolumn{3}{c}{ b. All requested variables entered. } \\
\hline
\end{tabular}

\begin{tabular}{ccccc}
\hline \multicolumn{5}{c}{ Model Summary } \\
\hline Model & $\mathrm{R}$ & R Square & $\begin{array}{c}\text { Adjusted R } \\
\text { Square }\end{array}$ & $\begin{array}{c}\text { Std. Error of the } \\
\text { Estimate }\end{array}$ \\
\hline $\mathrm{I}$ & $.403^{\mathrm{a}}$ & .162 & .154 & .77984 \\
\hline \multicolumn{4}{c}{ a. Predictors: (Constant), ALTRUISM } \\
\hline
\end{tabular}




\begin{tabular}{|c|c|c|c|c|c|c|}
\hline \multicolumn{7}{|c|}{$\mathrm{ANOVA}^{\mathrm{a}}$} \\
\hline & Model & Sum of Squares & $\mathrm{df}$ & Mean Square & $\bar{F}$ & Sig. \\
\hline \multirow[t]{3}{*}{$\mathrm{I}$} & Regression & I I.539 & $\mathrm{I}$ & II.539 & 18.975 & $.000^{\mathrm{b}}$ \\
\hline & Residual & 59.598 & 98 & .608 & & \\
\hline & Total & 7I.138 & 99 & & & \\
\hline \multicolumn{7}{|c|}{ A. Dependent Variable: Environmental attitude } \\
\hline \multicolumn{7}{|c|}{ B. Predictors: (Constant), Altruism } \\
\hline \multicolumn{7}{|c|}{ Coefficients $^{\mathrm{a}}$} \\
\hline \multirow{3}{*}{\multicolumn{2}{|c|}{ Model }} & Unstandardized & oefficients & Standardized & $\mathrm{t}$ & Sig. \\
\hline & & & & Coefficients & & \\
\hline & & $\mathrm{B}$ & Std. Error & Beta & & \\
\hline \multirow[t]{2}{*}{$\mathrm{I}$} & (Constant) & 2.263 & $.3 \mathrm{I} 4$ & & 7.209 & .000 \\
\hline & $\begin{array}{c}\text { ALTRUIS } \\
\text { M }\end{array}$ & .370 & .085 & .403 & 4.356 & .000 \\
\hline
\end{tabular}

a. Dependent Variable: Environmental attitude

Interpretation: Above result shows that value of significant is .000 so there is perfect relation between above variables. Our hypothesis is accepted and there is perfect relation. Value of R square is .I54 which means IV can cause I5\% change in DV.

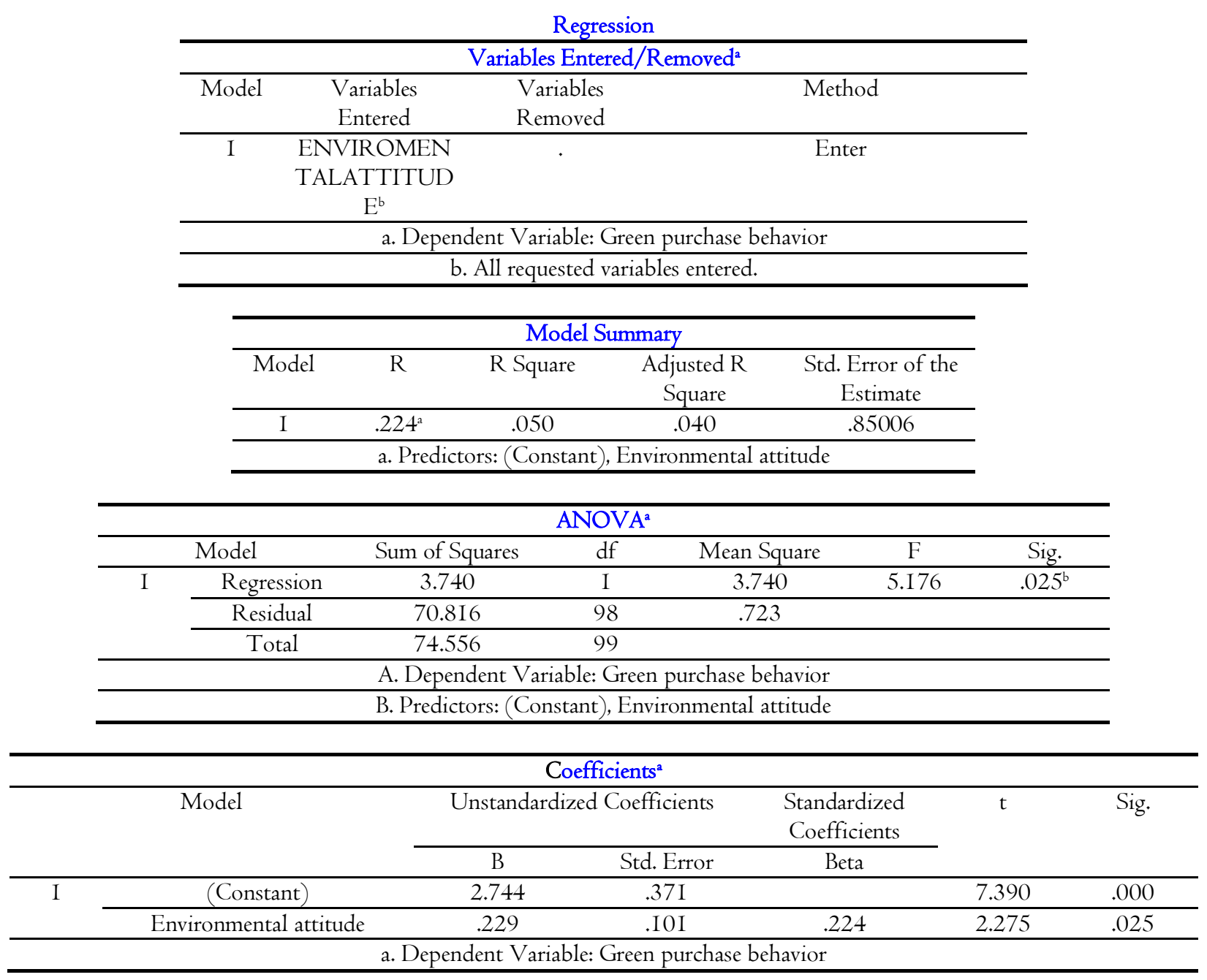


Interpretation: According to ANOVA table value of significant is 0.25 which is less than 0.05 so our hypothesis is accepted that there is significant relationship between green purchase behavior and environmental attitude. The value of $R$ square is 0.50 which means environmental attitude can influence GPB up to $5 \%$

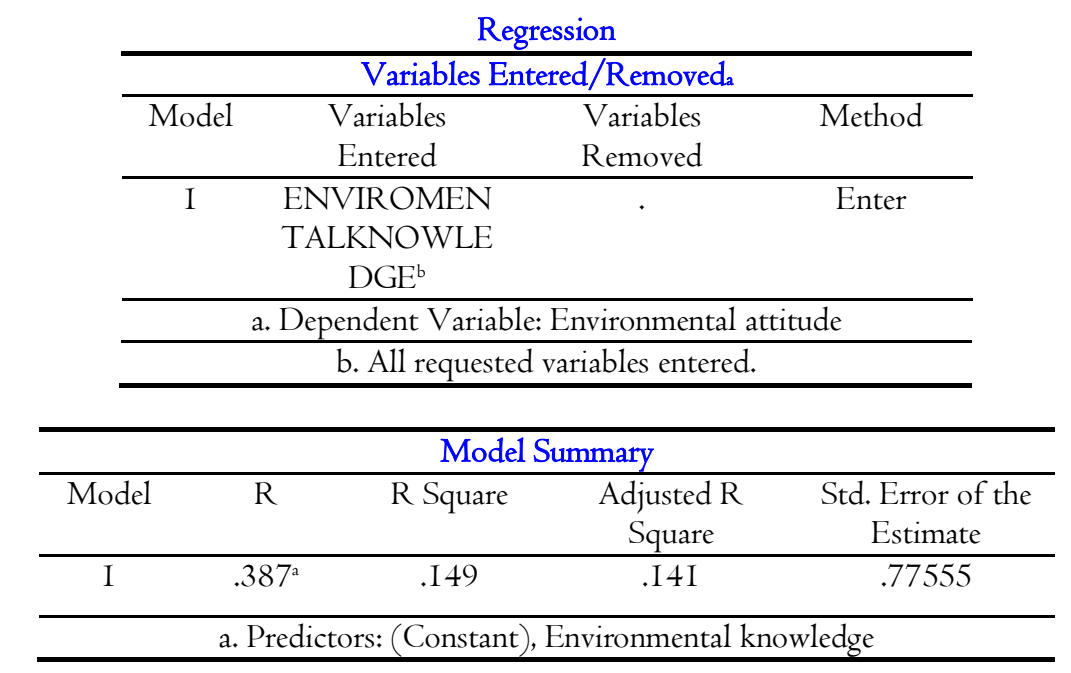

\begin{tabular}{ccccccc}
\hline \multicolumn{7}{c}{ ANOVA $^{\mathrm{a}}$} \\
\hline \multirow{2}{*}{$\mathrm{I}$} & Model & Sum of Squares & $\mathrm{df}$ & Mean Square & $\mathrm{F}$ & Sig. \\
\cline { 2 - 6 } & Regression & $\mathrm{I} 0.252$ & $\mathrm{I}$ & $\mathrm{I} 0.252$ & $\mathrm{I7.044}$ & $.000^{\mathrm{b}}$ \\
\cline { 2 - 6 } & Residual & 58.343 & 97 & .601 & \\
\hline & Total & 68.595 & 98 & & \\
\hline \multicolumn{5}{c}{ A. Dependent Variable: Environmental attitude } \\
\hline
\end{tabular}

\begin{tabular}{|c|c|c|c|c|c|c|}
\hline \multicolumn{7}{|c|}{ Coefficients $^{a}$} \\
\hline \multirow{3}{*}{\multicolumn{2}{|c|}{ Model }} & Unstand & Coefficients & Standardized & $\mathrm{t}$ & Sig. \\
\hline & & & & Coefficients & & \\
\hline & & $\mathrm{B}$ & Std. Error & Beta & & \\
\hline \multirow[t]{2}{*}{$\mathrm{I}$} & (Constant) & 2.380 & .306 & & 7.776 & .000 \\
\hline & Environmental knowledge & .359 & .087 & .387 & 4.128 & .000 \\
\hline
\end{tabular}

Interpretation: According to above table value of significant is .000 so there is perfect relation between environmental knowledge and environmental attitude so our hypothesis is accepted. The value of R square is .I49 so IV can cause I4\% change in DV

\begin{tabular}{|c|c|c|c|c|}
\hline & \multicolumn{4}{|c|}{ Regression } \\
\hline \multicolumn{5}{|c|}{ Variables Entered/Removed ${ }^{\mathrm{a}}$} \\
\hline \multirow{2}{*}{\multicolumn{2}{|c|}{ Model }} & Variables & Variables & Method \\
\hline & & Entered & Removed & \\
\hline & \multirow[t]{3}{*}{$\mathrm{I}$} & ENVIROMEN & . & Enter \\
\hline & & TALATTITUD & & \\
\hline & & $E^{b}$ & & \\
\hline & \multicolumn{4}{|c|}{ A. Dependent Variable: Green purchase behavior } \\
\hline & \multicolumn{4}{|c|}{ b. All requested variables entered. } \\
\hline \multicolumn{5}{|c|}{ Model Summary } \\
\hline \multirow[t]{2}{*}{ Model } & & R Square & Adjusted R & Std. Error of the \\
\hline & & & Square & Estimate \\
\hline \multirow[t]{2}{*}{$\mathrm{I}$} & & .050 & .040 & .85006 \\
\hline & \multicolumn{4}{|c|}{ A. Predictors: (Constant), Environmental attitude } \\
\hline
\end{tabular}




\begin{tabular}{ccccccc}
\hline \multicolumn{7}{c}{ Anova $^{\text {a }}$} \\
\hline \multirow{3}{*}{$\mathrm{I}$} & Model & Sum Of Squares & Df & Mean Square & F & Sig. \\
\cline { 2 - 6 } & Regression & 3.740 & I & 3.740 & 5.176 & $.025^{\text {b }}$ \\
\cline { 2 - 6 } & Residual & 70.816 & 98 & .723 & \\
\cline { 2 - 6 } & Total & 74.556 & 99 & \\
\hline \multicolumn{5}{c}{ A. Dependent Variable: Green purchase behavior } \\
\hline
\end{tabular}

\begin{tabular}{|c|c|c|c|c|c|c|}
\hline \multicolumn{7}{|c|}{ Coefficients $^{a}$} \\
\hline \multirow{2}{*}{\multicolumn{2}{|c|}{ Model }} & \multicolumn{2}{|c|}{ Unstandardized Coefficients } & Standardized & \multirow[t]{2}{*}{$\mathrm{T}$} & \multirow[t]{2}{*}{ Sig. } \\
\hline & & $\mathrm{B}$ & Std. Error & Beta & & \\
\hline \multirow[t]{2}{*}{ I } & (Constant) & 2.744 & .371 & & 7.390 & .000 \\
\hline & $\begin{array}{l}\text { ENVIROMENTALATTIT } \\
\text { UDE }\end{array}$ & .229 &. $\mathrm{IOI}$ & .224 & 2.275 & .025 \\
\hline
\end{tabular}

A. Dependent Variable: Green purchase behavior

Interpretation: According to ANOVA table value of significant is 0.25 which is less than 0.05 so our hypothesis is accepted that there is significant relationship between green purchase behavior and environmental attitude. The value of $R$ square is 0.50 which means environmental attitude can influence GPB up to $5 \%$.

\section{Conclusion}

This research helps marketers to predict key indicators of young consumer green purchase behavior. It also helps marketers to understand divers and barriers to green purchase behavior. With clear idea marketers can formulate strategies to encourage green purchase behavior. Marketers and Government policy makers should publicize information regarding environmental is sues to encourage youngsters to purchase green products. Young consumer's altruistic orientation proposes that youngsters genuinely care for environment. So, these youngsters can be target market for marketers. These young consumers will be adults in future. Among youngsters there is thought sharing process. Through information sharing process youngsters gain knowledge and this knowledge leads to development of altruism and interpersonal influence effectuate environmental attitude which leads to green purchase behavior.

\section{References}

Axelrod, L. J., \& Lehman, D. R. (I993). Responding to environmental concerns: What factors guide individual action? Journal of Environmental Psychology.

Busse, M., \& Menzel, S. (20I4). The role of perceived socio-spatial distance in adolescents' willingness to engage in proenvironmental behavior. Joumal of Environmental Psychology, 40, 4I2-420.

Breckler, S. J. (1984). Empirical validation of affect, behavior, and cognition as distinct components of attitude. Journal of Personality and Social Psychology, 47(6), I I9I-I205.

Bearden, W. O., Netemeyer, R. G., \& Teel, J. E. (I989). Measurement of consumer susceptibility to interpersonal influence. Journal of Consumer Research, I5(4), 473-48I.

Cheah, I., \& Phau, I. (20II). Attitudes towards environmentally friendly products: The influence of ecoliteracy, inter- personal influence and value orientation. Marketing Intelligence \& Planning, 29(5), 452-472.

Caruana, and Rosella Vassallo. (2003). Children's perception of their influence over purchase.

Chan, R. Y. K., \& Lau, L. (200I). Explaining green purchasing behavior: A cross-cultural study on American and Chi- nese consumers. Journal of International Marketing, I4(2/3).

Chen, T. B., \& Chai, L. T. (2010). Attitudes towards the environment and green products: Consumers' perspective. Management Science and Engineering.

Davies, J., Foxall, G. R., \& Pallister, J. (2002). Beyond the intention behaviour mythology: An integrated model of recycling. Marketing Theory, 2(I), 29-I I4.

Gruber, V., Schlegelmilch, B.B. (2014). How Techniques of Neutralization Legitimize Norm- and Attitude-Inconsistent Consumer Behavior. J Bus Ethics I2I, 29-45.

Gurau, C. \& Ranchhod, A., International green marketing: A comparative study of british and romanian firms.

Gueguen, N., \& Stefan, J. (2016). "Green Altruism » : Short Immersion in Natural Green Environments and Helping Behavior. Environment and Behavior, 48, 324-342. 
Haryanto, B. \& Budiman, S. (2014). The Role of Environmental Knowledge in Moderating the Consumer Behavioral Processes Toward the Green Products (Survey on the Green Product-mind in Indonesian).

Khan, M. N., \& Kirmani, M. D. (2015). Influence of environ- mental characteristics of the consumers on their willingness to pay for green products: An empirical investigation. Inter- national Journal of Social Entrepreneurship and Innovation, 3(5), 374-386.

Khan, K. M., \& Khan, M. N. (2006). The encyclopaedic dictionary of marketing. New Delhi, India: Sage.

Lee. (2009). Gender differences in Hong Kong adolescent consumers' green purchasing behavior. Journal of Consumer Marketing, 26(2), 87-96.

Mendleson, N. \& Polonsky, M.J. (I995) Using strategic alliances to develop credible green vegetables in Scotland, Journal of Consumer Marketing, I2(2), pp I8-24.

Moses, K. (2000). Cell fate specification in the Drosophila retina. Fini, 2000 : 93 --I I4.s: the role of parental communication patterns.

Milfont, T. L., \& Duckitt, J. (20I0). The environmental attitudes inventory: A valid and reliable measure to assess the structure of environmental attitudes. Journal of Environmental Psychology, 30(I), 80-94.

Matear, S. \& Gray, R. (I993). Factors Influencing Freight Service Choice for Shippers and Freight Suppliers", International Journal of Physical Distribution \& Logistics Management, 23 (2), 25-35.

Olejniczuk-Merta A. (200I). Rynek młodych konsumentów, Delfin, Warsaw.

Ramayah, T., Lee, J. W. C., \& Mohamad, O. (2010). Green product purchase intention: Some insights from a developing country. Resources, Conservation and Recycling, 54(12), I4I9-I427

Robert L. Shrigley , Thomas R. Koballa Jr. The University of Texas at Austin, Austin, Texas 787I2

S. M. Fatah Uddin \& Mohammed Naved Khan. (2018).Young Consumer's Green Purchasing Behavior: Opportunities for Green Marketing, Journal of Global Marketing, DOI: I0.1080/089 I 1762.2017.I407982

Syahbandi. (2012). Implementasi Green Marketing Melalui Pendekatan Marketing MIX, Demografi Dan Pengetahuan Terhadap Pilihan Konsumen (Studi The Body Shop Pontianak). Jurnal Ekonomi, Bisnis dan Kewirausahaan, 3 (I), 68-86.

Uddin, S. F., \& Khan, M. N. (2016a). Exploring green purchasing behaviour of young urban consumers. South Asian Journal of Global Business Research, 5(I), 85-103.

Uddin, S. F., \& Khan, M. N. (2016b). Green purchasing behaviour of young Indian consumers: An exploratory study. Global Business Review, I7(6), I469-I479

Vermeir, I. and W. Verbeke (2004), Sustainable food consumption, involvement, certainly and values: an application of the theory of Planned Behavior, Working Paper, Department of Agricultural Economics, Ghent University, Ghent.

Wheale, P., \& Hinton, D. (2007). Ethical consumers in search of markets. Business Strategy and the Environment, I6(4), 302315.

Copyrights

Copyright for this article is retained by the author(s), with first publication rights granted to the journal. This is an open-access article distributed under the terms and conditions of the Creative Commons Attribution license (http://creativecommons.org/licenses/by/4.0/). 